VITALII HURA,

Ukrainian Evangelical Seminary (Kyiv, Ukraine)

e-mail: guravit@gmail.com, ORCID0000-0002-1207-3085

\title{
MODERN UKRAINIAN PENTECOSTAL THEOLOGY: FROM HISTORY OF DEVELOPMENT TO CONTENT OF RESEARCHES
}

\begin{abstract}
The article reflects the main historical stages of the formation of Ukrainian Pentecostal theology over the past thirty years: from the "birth" of the first church schools to the defense dissertations of doctoral level. Author has presented connection between post-soviet Pentecostal dogmatic system with evangelical traditional of dispensationalism and literal hermeneutic method in study of the Bible. Obviously, that Pentecostal Churches were strongly influenced through the Baptist Bible Courses in Moscow, because many Pentecostal leaders completed them. The author demonstrated the role of Bible Seminaries founded in independent Ukraine by western missioners of leading church's unions, like the Assembly of God and the Church of God. The article identifies two models of the Pentecostal education ("church" and "academic" approaches) that address to the different needs of church society. "Church" type of theological education tries to teach important topics connected with applied questions of church ministry. However, this approach has a weak side hidden in methodology of research. As a result, not all research papers completed by graduates of the church-oriented school are interesting for Ukrainian scientific society. For control of quality in Ukrainian theological schools, EAAA was founded. Another direction of the development of the Ukrainian pentecostal theological model thinking is the "academic model" of theological education, that today develops in cooperation with state institutions. Through the analysis of the topics of defended dissertations, the author identifies key trends in the development of the Ukrainian Pentecostal movement. Among key topics, there is introspective research of the own roots, reasons of spreading alternative church movement in USSR, and its place on the World religious map. Like prognostic conclusion of all the text, the author identified several topics that may be interesting for Western academic partners, like "theology of Maidan", "Church peaceful strategies for East of Ukraine" and "Ecological theology in light of Chernobyl's tragedy".
\end{abstract}

Key word: modern Pentecostal theology; Ukrainian Pentecostal education; Ukrainian Pentecostal Church Union; Christians of the Evangelical Faith, Pentecostal theological researches.

Introduction

In 2021, it will be 100th anniversary since the establishment of the Pentecostal Movement in Ukraine. According to Kirsteen Kim, despite the fact that, at the beginning of this new spiritual Movement in USA, the leaders of Pentecostal Churches were more focused on the personal experience rather than on education itself, today, many prominent theologians have Pentecostal or charismatic background (Kim, 2017: 22). K. Kim also shows that the reflection about this Movement has a profound theological influence not only on the pentecostals, but also on the representatives of ecumenical theology (Kim, 2017: 22). We appreciate the contribution made by the World leaders of academic Pentecostal theology (such as Amos Yong (2002), Veli-Matti Karkkainen (2008), etc.) to the development of global theology. Moreover, in this reason, we have some reasonable questions: "What kind of contribution can Ukrainian Pentecostal theologians do for the development of modern theology of the World Pentecostal Movement?", or "What is Ukrainian Pentecostal theology today?" and "What kind of our experiences and achievements may be of interest to foreign scholars?"

Obviously, the answers to these questions can be found during introspective analysis of one's own historical

ISSN 1728-9343 (Print)

ISSN 2411-3093 (Online) path and the formulation of one's own theological identity. Accordingly, in this article, we have proposed an attempt to comprehend the theological worldview of the Pentecostals formed over the past thirty years and reflected in the research performed.

The main purpose of this article is to analyze the historical and theological way of formation of modern Pentecostal theology in Ukraine by identifying key stages in the development of theological education and analysis of topics of doctoral dissertations for the past three years.

Research methods

For this research, we have used the historical method, method of comparative analysis and the method of theoretical modelling.

Previous researchers, who also studied some various aspects of Pentecostal theological education, were M.M. Mokiyenko (2018) (the role of theological education in the process of forming national Pentecostal Unions), V.L. Khromets (2018) (legal support of theological education in independent Ukraine), A.V. Nechyporuk (2020) (quality management of education in Pentecostal educational institutions of Ukraine).

SKHID Vol. 1 (1) January-February 2021 


\section{Results and Discussion}

Historically, on the territory of the former USSR, the first theological formulations with specific Pentecostal dogmas were published in the official documents of the religious organizations prepared by leader of Pentecostals I.E. Voronaeff (1885-1937) and by bishop A.I. Bidash (1901-1978) (Franchuk, 2002). In addition, there was a deep influence of publications of the lecture material of teachers from the Bible Institute in the Polish city Danzig (Gdansk) under the leadership of G.H. Schmidt during 1932-1939 on outlook of churches (Yarotskyy, 2008: 7374 ). We have studied the papers of confessions of Pentecostal faith and have made conclusion that base of worldview of Ukrainian Pentecostals consisted of doctrines of dispensationalism with broad using of the methods of literal hermeneutics (Hura, 2018). In the center of church life of early pentecostals in Ukraine there was personal pneumatological experience and high moral standards of everyday life. It is the feature of Pentecostal theology that is perceived as the organic feature of the worldview of the Christians of the Evangelical Faith (another name of Ukrainian Pentecostals).

Many dogmatic formulations of the modern Ukrainian Pentecostals were historically connected with the Moscow Bible Courses for pastors of the Baptist Churches in USSR. These Courses were established in 1967 by the All-Ukrainian Union of the Churches of Evangelical Christians-Baptists in Moscow. It was single pastor school for all Baptist and Pentecostal churches in Soviet Union and only very important person could become a student at this school. Every candidate for studying had to be a member of the legal Baptist Church Union. Among alumni of these Courses, we know very famous Pentecostal leaders, like M.A. Gushchin (1928), N.P. Reschikovets (1945), M.S. Panochko (1951), A.I. Klinovskiy (1952-2019), and others. According to the comparative analysis of the content of the lectures of these Courses, we can see that graduated preachers very often used the topic forms of the Bible Courses for their lectures at their churches. Knowledge obtained during studies at the Bible Courses has influenced the Pentecostal ideas about the art of preaching ("Homiletics"), musical standards, pastoral theology and understanding of the philosophy of Church history (correlation of the history of Christianity with the seven periods of the Book of Revelation). Thus, the first Pentecostal educational institution in Ukraine was established with strong influence of Baptist authors, retaining only the pneumatological emphasis on the Pentecostal experience.

A particular exception from this model is the content of the theological education of illegal Pentecostal Union. They did not have open access to the Bible Courses in Moscow. After the fall of USSR, this wing of "unregistered" Pentecostals opened own Bible College in Rybnitsa (Moldova) in 1993. The main aim of this institution was the preparation of church leaders and ministers from all former USSR. The curriculum of the short-term training courses for evangelical preachers was based on the author's lectures by bishops Viktor Byelyh (19252001) and Mykola Kotyakov (1952-2018). Analysis of the content of the curriculum and the lectures shows us the indirect influence of the materials of Bible Courses in Moscow at the topics of "Homiletics" and "History of Christianity". The Soviet period with its rigid anti-religious policies complicated the conduct of creative approach in research of theological issues and narrowed the focus of church leaders to a limited list of topics. For example, eschatology was considered as an anti-Soviet topic and was forbidden by law. Every preacher could be convicted for lectures or teaching topics about the "Millennium", "Kingdom" or "The Second Coming of Christ" under an article of the Criminal law of the USSR.

The institutionalization of Ukrainian theological education began with the establishment of Pentecostal Schools:

- 1989 Theological Seminary and Academy (city Rivne);

- 1991 Seminary of Practical Theology (city Korosten);

- 1992 Ukrainian Evangelical Theological Seminary (capital of Ukraine Kyiv);

- 1993 Kyiv Bible Institute.

The main purpose of founding the theological schools was fulfillment of everyday practical needs of local churches of ministers: preachers, missionaries, Sunday school teachers, and music leaders. By the efforts of missionaries and teachers from the USA and Canada, during short period several groups of national teachers for various theological subjects were prepared. In 1999, the Lviv Theological Seminary was opened under the leadership of A.I. Klinovskiy.

During the period from 1990 to 2000 , the first teachers with academic degrees were those scholars who became Christians and joined to the Pentecostal Churches. Among them there was well known Dr. Victoriya Lyubashchenko from Lviv. She was the first author who summarized the history of evangelical Christians in one textbook: "History of Protestantism in Ukraine" (Lyubashchenko, 1996). Another kind of the Pentecostal teachers with high-level degrees were doctors in philosophy in technical sciences rev. Victor Shevchuk and rev. Valeriy Reshetynskiy. The presence of these teachers with state academic degrees and administrative experience in the leadership of Pentecostal Church Union in department of education made a positive effect and stimulated many seminaries to increase of level of their theological education.

Therefore, in 1990-2000, in addition to organizational problems, education promoters experienced the psychological barrier of church leaders reluctant to send church members for studying. It is important to note that during the period of Soviet rule, in outlook of many of church members, strong negative attitude towards theological education was created as the action against the grace of the Holy Spirit. They began to believe that theological education was not useful for preparation of church ministers because it prevented them from hearing God and doing His will.

The Evangelical Theological Seminary was founded in Kyiv in 2000 by the missionaries of the Assembly of God of USA. In 2000-2008 ETS became the center for affordable and high-quality American theological education for Pentecostal ministers from many different countries of former USSR. Here they studied ancient biblical languages, theory and practice of exegesis, systematic and biblical theology. The students rethought their own church tradition, expanding the list of their own research topics. During this period, theological identity was formed through the classical works of prominent Pentecostal scholars, like S. Horton (1999) and W. Menzies (1999). An important step in the process of recognizing a national theological thought was done in 2012, when the Academic Council of the National University "Ostrog Academy" 
had awarded an honorary degree of "Doctor of Theology" to the Pentecostal bishop Vasyl Boyechko from Lviv. University scholars honored his work for update Ukrainian translation of the Bible (2006) with commentaries of the Pentecostal theologian D. Stamps (also known as "Fire Bible"). V.M. Boyechko is well-known national author of theological books on current church topics about many issues: understanding of marriage, anthropology, pneumatology, interdenominational relations and key historical events. For example, in the book "The temple of the Holy Spirit" V. Boyechko (2003) laid down fundamental ideas about doctrine of the spiritual baptism and gifts. In the book "Unconquered Church" (2010) the author reveals the keys facts of Ukrainian Pentecostal Movement in each of regions of Ukraine during communistic and democratic periods of history. Very special eschatological model of future based on allegoristic hermeneutics was presented in the book "The end for all things is very close" (2005). Dissemination of works by V.M. Boechko has made important contribution to the formation of selfidentification of Ukrainian Pentecostals on the religious map.

On August 31, 2018 in the House of Prayer of the Ukrainian Pentecostal Church (Ivano-Frankivsk city) a significant event on the development of church education in the Pentecostals Church Union of Ukraine took place: the graduation ceremony of groups of Doctors of Theology and Doctors of Ministry. The graduates received diplomas from several Pentecostal institutions: Chernivtsi Bible Seminary, Lviv Theological Seminary and Slavic University of Washington (USA).

In 2018 and 2020 at the Evangelical Theological Seminary (Kyiv) in collaboration with professors from the "Assembly of God of the United States", two more groups of Doctors of Ministry/Doctors of Practical Theology were graduated. The ETS graduates focused on the study of practical issues of church service and questions of Church history. There are some examples of topics:

-"The Slavic Pentecostal Movement in Argentina" (V. Franchuk);

-"The Missionary Experience of the Slavic Pentecostal Missionaries in Mozambique" (O. Romanyuk);

-"The Models of Relations between the Ukrainian Pentecostal Church and Society" (O. Skrypnik);

-"Pentecostal Eschatology" (I. Azanov);

-"Pentecostal Theological Education" (A. Nechyporuk);

- "Children Ministry in the Ukrainian Pentecostal Churches" (P. Zhmur);

- "The Systematic Thanatology: the theology of death" (S. Seletskiy) etc.

This project became the best in Church Education Department at Ukrainian Pentecostal Union. Nevertheless, national pentecostals received a good opportunity for the theology development in high academic environment of State Universities.

In generally, the academic theological education has started its development through ministry of EAAA. The Euro-Asian Accreditation Association (EAAA) has made a significant contribution to the formation of the academic theological discourse of the Evangelical Churches of former USSR. EAAA was founded in 1997 and quickly became the institutional flagship for the implementation of international standards of theological education among many Evangelical Church Unions. The net of EAAA united about 50 theological schools from different countries of former USSR and become "a bridge" with a state and evangelical institutions in implementation of academic standards (EAAA, 2009).

Today in Ukraine, academic theological fellowship of Pentecostal leaders was formed. They are open for dialogue both with national evangelical environment and with global Christianity.

At the moment, EAAA continues work on implementation of international standards for the accreditation of theological schools, seminaries, annual institutes of professional development (in cooperation with "Overseas Council" and the "Ukrainian Doctoral Program" project).

A quite big project of EAAA was "The Slavic Biblical Commentary", which was created by the 94 Slavic theologians under the general editorship of Dr. Sergiy Sannikov (2016).

Since the 2000s, the Ukrainian Pentecostals have formed a young generation of teachers who got their doctoral degree in history (Roman Soloviy (in 2001) and Mikhail Mokiyenko (in 2006). Then they began to develop Ukrainian academic Pentecostal theology based on scientific methodology. The early works of these authors may help to understand the origins of the World Pentecostal Movement and the socio-political aspect of the development of late Protestantism in the first two decades of Ukraine's independence.

In 2010 "Theology" as branch of philosophical science was included to the national state list of specialties. Since 2010, Ukrainian education law demonstrated deep loyalty to the theological education process. During 2014-2018 Ukrainian theologians received good opportunity for legalization of all diplomas issued by different theological schools. For this purpose, a candidate for legalization had to give all papers to the Counsel of Ministry of Education and Science of Ukraine. The process of state recognition of theological diplomas issued by religious educational institutions offered good opportunity to continue theological education at the National Pedagogical Dragomanov University or University of Education Management etc. for many Protestants.

A significant event for the entire evangelical society of Ukraine took place on April 28, 2017, when the Pentecostal theologian Roman Soloviy obtained the degree of Doctor of Philosophical Science (with specialty in theology 09.00.14). The thesis was defended at a special Academic Council of the National Pedagogical Dragomanov University headed by professor Dr. Yuriy Chernomorets. The author explored the phenomenon of the "Emerging Church" and demonstrated new horizons of understanding ecclesiology in the context of world philosophical and theological thought. Roman Soloviy introduced a large number of sources into scientific field, and demonstrated models of religious society response to modern challenges of the postmodern world (Soloviy, 2016).

On October 9, 2018, Mikhailo Mokiyenko was another Ukrainian Pentecostal minister who defended thesis for the habilitation degree of Doctor of Philosophical Science (with specialty in theology 09.00.14). The topic of the thesis was "Pentecostalism: features of theological and social identification". This research demonstrated a new level of introspective understanding of the role and place of Ukrainian Pentecostals in the World tradition and the transition of Ukrainian academically philosophical science to a pluralistic worldview after Soviet period. In scientific circles of modern democratic Ukraine, there is a significant tolerance to the representatives of Protestantism and 
Pentecostals. We have to remember that during Soviet period Pentecostal Church was forbidden, many preachers were imprisoned. Moreover, in 1970 S.K. Marzanova defended a thesis about "Anti-scientific essence of Pentecostalism in Bulgaria" for the doctoral degree at Moscow State University (Marzanova, 1970).

During 2017-2020, a number of Pentecostals and charismatic leaders defended their dissertations on "The- ology" and "Religious studies" at Dissertation Councils at National Pedagogical Dragomanov University and the Institute of Philosophy of the National Academy of Sciences of Ukraine. The analysis of the subjects of the researches allows us to reveal the tendencies of theological thought in the middle of Church Unions.

We can divide all defended thesis for two groups: "content researchers" and "path researchers".

Table 1. - List of topics of dissertations defended by Pentecostals during 2017-2020 at State Universities

\begin{tabular}{|c|c|c|}
\hline \# & Name & Topic \\
\hline \multicolumn{3}{|c|}{ Habilitation Degree: Doctor of Philosophical Science in Theology } \\
\hline 1 & Soloviy R.P. & $\begin{array}{l}\text { The Phenomenon of the "Emerging Church" in the Context of Theological and } \\
\text { Ecclesiological Transformations in Modern Western Protestantism. }\end{array}$ \\
\hline 2 & Mokiyenko M.M. & The features of theological and social identification of Pentecostal movement \\
\hline \multicolumn{3}{|r|}{ Degree of Doctor of Philosophy in Theology } \\
\hline 3 & Bornovolokov O.V. & The identity of the Ukrainian Pentecostal movement \\
\hline 4 & Hura V.O. & Eschatology of Pentecostals (Christians of the Evangelical Faith) \\
\hline 5 & Denysenko A. & The critical analysis of Liberation Theology \\
\hline 6 & Kartayev V. & The critical analysis of Open Theism \\
\hline 7 & Rusin I.I. & Missionary Theology by Lesslie Newbigin \\
\hline 8 & Tischenko A.G. & $\begin{array}{l}\text { Features of the formation and institutionalization of Charismatic Churches in } \\
\text { modern Ukraine (on the example of the International Christian Movement "New } \\
\text { Generation"). }\end{array}$ \\
\hline 9 & Khromyak M.V. & Reception of personalization of St. Gregory of Nyssa in modern Theology. \\
\hline 10 & Khromyak N.L. & $\begin{array}{l}\text { The Doctrine of Natural Theology by Karl Bart and its reception in Modern } \\
\text { Theological thought. }\end{array}$ \\
\hline 11 & Shevchuk P.V. & Political Theology of Radical Orthodoxy. \\
\hline
\end{tabular}

The first group did the research on understanding the historical and theological conditions of development of the Ukrainian Pentecostal movement and origins of content of their doctrines. The researchers determined the place of the national Pentecostal movement in relation to 11,000 Pentecostal denominations of the World that represents $600,000,000$ Pentecostals and charismatics worldwide.

For his research, M.M. Mokiyenko used the methodology by Amos Yong (Spirit-Word-Community) and explored Pentecostalism as a religious phenomenon for focus on a comprehensive critical analysis of the movement (Yong, 2002). The authors well reveal the theological and social features of the identification of Ukrainian Pentecostal movement in the context of the main theological and ecclesiological models (Mokiyenko, 2018).

Oleg Bornovolokov focused on the study of historical and theological features of the process of institutionalization of Pentecostal churches in Ukraine as a determining factor in the formation of the identity of the national Pentecostal movement during 1929-1939. (Bornovolokov, 2019).

The study of the sources of doctrine and the conditions of development of the dogmatic of the Soviet Pentecostals was completed in the thesis by Vitalii Hura. He based the research on exploring specifics features of Ukrainian Pentecostal eschatological doctrine on the example of the process of formation of local theological systems according the methodology by Robert Schreiter (Hura, 2019). The applied methodology allowed V. Hura to reconstruct the process of formation of Pentecostal doctrines in former USSR and offer for readers a forecast of changes in the Pentecostal model of future due to changes in the content of basic theological concepts (Hura, 2019).

Another researcher, Andrey Tishchenko is the senior bishop of the Ukrainian Union of Charismatic Churches (known as "New Generation"). His thesis deserves special attention. The researcher focused on identifying the essence of the processes of formation and institutionalization of charismatic Churches in modern Ukraine.

His research methodology is based on identifying the specifics of charismatic doctrines as a component of charismatic theology at the stage of its constitution, and the organizational structure of charismatic Churches due to their evangelistic mission (Tishchenko, 2020). The thesis was prepared on the example of the charismatic International Christian Movement "New Generation".

Thus, today in the Ukrainian academic environment, there is a dynamic process of understanding the history, sources, content and diversity of Pentecostal doctrines and practices. Some researchers also take into account possible combinations of Pentecostal doctrine with practices of neo-Pentecostal (charismatic) embodiments of pneumatological ideas in church worship.

The second group of Pentecostal researches include studies devoted to the search for the theological path of the Pentecostals in dialogue with various theological concepts of the past and present times. For examples: "The Theology of liberation" (Anatoliy Denysenko) "Natural Theology of Karl Bart" (Nataliya Khromyak), "Patristic Theology of St. Gregory of Nyssa in the light of Modern 
Theology" (Mikhail Khromyak), "Political Theology of Radical Orthodoxy" (Pavlo Shevchuk) and "Open Theism" (Volodymir Kartayev).

Ivan Rusin performed understanding the role of mission tasks of evangelical churches through a comprehensive analysis of the missionary Trinitarian theology of Lesslie Newbigin. The author of the thesis emphasizes that the Trinitarian understanding of conception "Missio Dei" means that the God's Mission has the beginning and the end only in the eternal relationship of love between the parts of the Holy Trinity (Father, the Son and the Holy Spirit) (Rusin, 2019: 4-5). This example of relationship became model in the practice of implementation of "missionary ecclesiology".

The monography of Roman Soloviy "The Phenomenon of the Emerging Church in the Context of Theological and Ecclesiological Transformations in Modern Western Protestantism" has a special place among thesis of Ukrainian Pentecostal scholars.

The main purpose of the author is to conceptualize the worldview, theological and ecclesiological features of the model of "Emerging Church" as an alternative innovative direction of Western Protestantism.

R.P. Soloviy in the thesis has formulated the concept of the "Emerging Church"

"...as an alternative and innovative trend in modern Western evangelical Protestantism, whose theological postulates and ecclesiological practices are adapted to the socio cultural and religious tendencies of postmodernism. The main characteristics of the church include orthopraxis, focus on personal and social transformation, and creative approach to liturgical practices. Important aspects of the identity of the movement are also the permanent deconstruction of theology, "humble" epistemology, the hermeneutic approach to reality, and the missionary imperative" (Soloviy, 2017:4).

In the dissertation, R.P. Soloviy has found that:

"The Emerging Church" develops decentralized, networked and anti-hierarchical forms of church organization. Church leadership models are dynamic, flexible, and open to change. Communities of the movement actively apply historical practices of spiritual formation, as well as introduce new methodologies of preaching ("progressive dialogue"), focused on the development of relationships between community members in the "sermon event". The Church is reviving the ancient liturgical practices of historical Christian traditions, conducting experiments on their creative adaptation using modern multimedia tools" (Soloviy, 2017: 32).

Research of R.P. Soloviy has proved to be exemplary in its quality and received approval from leading Ukrainian scientists (L. Filipovych, Y. Chornomorets, A. Baumaister and others) at the highest academic level.

Today, Dr. R.P. Soloviy develops Ukrainian academic theology through the involvement of national researchers in the study of philosophical and theological methodology at "Methodological Seminars", through publications in the journals "Theological Reflections" and "Bogomislie" as well as the development of the "The Eastern European Institute of Theology".

With the development of academic Pentecostal theology, there is a transformation of the methodology of theological research, the development of interchurch dialogue, the understanding of the own local theology within the global tradition of Christianity (Hura, 2018). Representatives of academic Pentecostal theology have demonstrat- ed their interest in a wide range of issues in contemporary theology, openness to academic dialogue and cooperation. All studies demonstrate a high level of mastery of research methodology and access of authors to oftenunique source databases.

\section{Conclusions}

Ukrainian Pentecostal theology emerged as a contextualized form of American dispensationalism, gradually taking the form of a local theological system.

Despite the prejudice of Ukrainian scientists against theological education, today in Ukraine we have near 15 Pentecostal higher theological institutions with state registration. All these institutions implement theological programs on the different levels like bachelor, master and doctoral programs. All programs have specializations in different fields (pastoral ministry, missions, Bible or systematic theology and history) and focus on academic standards of EAAA or state requirements.

Ukrainian academic Pentecostal theology also faces challenges that are interesting for Global Christianity. First, it is the search for ways to reconcile and restore Ukrainian society in the context of hostilities in East of Ukraine. The second is the comprehension of the "Theology of the Maidan" (or "Revolution of Dignity" in 2014) and the role of the Church in the political transformations of Ukrainian society in the light of the development of public theology of the Pentecostals. Third topic is an understanding of the consequences of the man-made catastrophe at the Chernobyl Nuclear Power Plant for the development of Ecological theology of Pentecostal as part of Global Christian doctrine of "responsibility for Creation". This is not an exhaustive list of all possible important topics, but it outlines the potential for further research that could be interesting for our Western partners.

Despite the intermediate successful results, Ukrainian Pentecostal theologians face the important task for development of new professional levels of researches, and cross-cultural dialogue for understanding of problems of modernity. For national scholars it may be possible through joining the Global Pentecostal Theological discourse, growing in using actual methodologies of theological research and active co-working with world professional associations (for example, the Society for Pentecostal Studies, USA).

It is expected that the future researches of Ukrainian Pentecostal theologians would be of interest for representatives of Global Pentecostal Theology and the tragic experience of Ukraine after comprehension would be useful for the development theology in the World Christianity.

\section{REFERENCES}

Bornovolokov, O. V. (2019). Identychnist ukrayinskoho pyatydesyatnytskoho rukhu: (PhD Dissertation). Kyiv, 228 p. (in Ukrainian).

Boyechko, Vasilyi (2005). Blizok vsemu konets. Lvov: Dobryy Samaryanin, 62 p. (in Russian).

Boyechko, Vasyl (2003). Khram Dukha Svyatoho. Lviv: Dobryy samaryanyn, $418 \mathrm{p}$. (in Russian).

Boyechko, Vasyl (2010). Neskorena Tserkva. Lviv: Dobryy Samaryanyn, 493 p. (in Ukrainian)

EAAA (2009). Akademicheskiye Standarty dlya programm lyuboy form obucheniya. Odessa: Yevro-Aziatskaya Akkreditatsionnaya Assotsiatsiya. 22 p. (in Russian).

Franchuk, Vladimyr (2002). Prosyla Rossyya dozhdya u Gospoda. Kyiv: Svitankova zorya, 648 p. Vol. 1 (in Russian). Horton, S. (1999). Sistematicheskoye bogosloviye (translate from Engl.) Sprigfild, Missuri, SSHA: Life, 1999. 935 s. (in Russian) 
Hura, V. (2019). Eskhatolohiya khrystyyan viry yevanhelskoyi (pyatydesyatnykiv). (PhD Dissertation). Kyiv, 268 p. (in Ukrainian)

Hura, V.(2018). Model «eskhatolohichnoyi ekleziolohiyi» nezareyestrovanykh pyatydesyatnykiv $\vee$ SRSR: istorykokulturni umovy rozvytku, sut ta suspilni naslidky. Praktychna filosofiya. 3 (69): 103-110. (in Ukrainian).

Karkkainen, Veli-Matti (2008). Pneumatology: The Holy Spirit in Ecumenical, International, and Contextual Perspective. Grand Rapids, MI, USA: Baker Academic, 250 p.

Khromets, V. (2018). Pochatok formuvannya normatyvnopravovoho zabezpechennya bohoslovs'koyi osvity v nezalezhniy Ukrayini. SKHID, 3 (155): 88-93. https://doi.org/10.21847/1728-9343.2018.3(155).139413 (in Ukrainian)

Kim, Kirsteen (2017). Pentecostalism and the Development of Theology of the Holy Spirit. Pentecost Journal of Theology and Mission. Oral Roberts University. 22.-32

Kulish, P. (translat., ed.) (2006). Bibliya z komentaryamy. Kyiv Printed in Belarus: Life Rublishers International, 2234 p. (in Ukrainian)

Lyubashchenko, V. I. (1996). Istoriya protestantyzmu v Ukrayini. Kyiv: POLIS, 1996350 p. (In Ukrainian).

Marzanova, S. K. (1970). Antinauchnaya sushchnost pyatidesyatnichestva $v$ Bolgarii. (PhD thesis) Moscow State University, 40 s. (In Russian)

Menzis, V. (1999). Bibliyni doktryny: pyatydesyatnyts'kyy pohlyad Sprinhfild, Miccuri, SSHA: Life, 1999. 332 s. (in Ukrainian)
Mokiyenko, M. M. (2018). Fenomen pyatydesyatnytstva. Rivne: Dyatlyk M., 440 s. (In Ukrainian)

Nechyporuk, A. (2020) Upravlinnya yakistyu osvity u zakladi vyshchoyi osvity UTSKHVYE : dys. dokt. prakt. bohoslov"ya: 09.00.14 ETU: Kyyiv, 2020. - 335 s. (in Ukrainian).

Rusin, I. I. (2019) Misionalna teolohiya Lesli Nyubihina (PhD Dissertation Thesis). Kyiv, 24 p. (in Ukrainian).

Sannikov, S. (2016). Slavyanskiy Bibleyskiy Kommentariy, YEAAA, Knigonosha, 2016. 1840 p. (in Russian).

Soloviy R. P. (2017) Fenomen Vynykayuchoyi tserkvy. U konteksti teolohichnykh ta ekleziolohichnykh transformatsiy u suchasnomu zakhidnomu protestantyzmi (Doctor Dissertation Thesis). Kyiv, 38 p. (in Ukrainian).

Soloviy, R. (2016). Odkrovennya i Pysannya: bohoslovs'ke osmyslennya Vynykayuchoyi tserkvy. Skhid. 1 (141): 76-82. https://doi.org/10.21847/1728-9343.2016.1(141).64817 (in Ukrainian).

Tishchenko, A. H. (2020). Osoblyvosti stanovlennya y instytualizatsiyi kharyzmatychnykh tserkov u suchasniy Ukrayini (na prykladi mizhnarodno khrystyyans'koho rukhu "Nove Pokolinnya"): (PhD dissertation thesis) Kyiv, 19 p. (in Ukrainian).

Yarotskyy, Petro (2008). Istoriya relihiyi v Ukrayini v 10-ty tomakh. Tom 6. Pizniy protestantyzm:p yatydesyatnyky, adventysty. Kyyiv-Drohobych: Surma, 632 p. (in Ukrainian).

Yong, Amos (2002). Spirit, Word, Community: Theological Hermeneutics in Trinitarian Perspective. Eugene: Wipf \& Stock Pub, $375 \mathrm{p}$.

Віталій Гура,

Украӥнська євангельська семінарія (м. Київ, Украӥна)

e-mail: guravit@gmail.com,ORCID 0000-0002-1207-3085

\section{СУЧАСНЕ УКРАЇНСЬКЕ П'ЯТИДЕСЯТНИЦЬКЕ БОГОСЛОВ'Я: ІСТОРІЯ РОЗВИТКУ ТА ЗМІСТ}

Стаття демонструє основні історичні етапи становлення української теорії п'ятидесятників за останні тридцять років: від зародження перших церковних шкіл до захищених дисертацій докторського рівня. Автор представив зв'язок між пострадянською догматичною системою п'ятидесятників 3 євангельською традицією диспенсаціоналізму та буквальним герменевтичним методом у вивченні Біблії. Очевидно, що Церкви П'ятидесятників отримали сильний вплив через баптистські курси Біблії в Москві, які там закінчили багато лідерів П'ятидесятників. Автор продемонстрував роль Біблійних семінарій, заснованих в незалежній Україні західними місіонерами провідних церковних союзів, таких як Асамблея Божа і Церква Божа. Визначено дві моделі п'ятидесятницької освіти (“церковний” та "академічний” підходи), що стосуються різних потреб церковного суспільства. "Церковний" тип богословської освіти намагається вивчати важливі теми, пов'язані з прикладними питаннями церковного служіння. Але цей підхід має слабку сторону, приховану в методології дослідження. Як результат, не всі наукові праці, закінчені випускниками церковно-орієнтованої школи, цікаві для українського наукового товариства. Для контролю якості в українських духовних школах було засновано EAAA. Ще одним напрямком розвитку української п'ятидесятницької теологічної моделі мислення є "академічна модель" теологічної освіти, яка сьогодні зростає у співпраці з державними установами. Проаналізувавши теми захищених дисертацій, автор визначає ключові тенденції розвитку українського руху п'ятидесятників. Серед ключових тем - інтроспективне дослідження власних коренів, причини поширення альтернативного церковного руху в СРСР та його місце на світовій карті релігій. Виділено декілька тем, перспективних для подальшої розробки українськими та зарубіжними дослідниками, зокрема "теологія Майдану", "Церковні мирні стратегії для Сходу України" та "Екологічна теологія у світлі Чорнобильської трагедії".

Ключові слова: місійна сучасне п'ятидесятницьке богослов'я; українська п'ятидесятницька освіта; ідентичність п'ятидесятників; Українська церква християн віри єваангельської; п'ятидесятницькі богословські дослідження.

(C) Vitalii Hura

Надійшла до редакції: 01.12.2020,

Прийнята до друку: 26.01.2021 